\title{
Eco-tourism in the Philippines: educational and recreational value of the Alayan cave systems
}

\author{
Cristina G. Gallato* \\ College of Business, \\ Universiti Utara Malaysia, \\ 06010 Sintok, Kedah, Malaysia \\ Email: cristina@uum.edu.my \\ *Corresponding author
}

\section{Kristy Aireen Gallato-Reamillo}

Hospitality and Tourism Department, Saint Paul University Philippines,

Quezon City, Philippines

Email: kristychie@yahoo.com

\author{
Nena P. Valdez \\ College of Arts and Sciences, \\ Universiti Utara Malaysia, \\ 06010 Sintok, Kedah, Malaysia \\ Email: nenzvaldez@yahoo.com
}

\author{
Ari Warokka and Haim Hilman \\ College of Business, \\ Universiti Utara Malaysia, \\ 06010 Sintok, Kedah, Malaysia \\ Email: ari.warokka@uum.edu.my \\ Email: hilman@uum.edu.my
}

\begin{abstract}
In this paper, we calculate the related costs of transport, food, accommodation and time involved as well as the rate of visits as compared to the costs, and the benefits from the Alayan Cave System (ACS), by using the Individual Travel Cost Method (ITCM) to determine the educational and recreational values of the site. Data came from the linear recreational demand for the site at the Department of Tourism - RO2 statistical records. We also determine the expenditures of the guests on off-site and on-site tourism-related activities and establishments to provide a more solid base for tourism policymakers, planners and decision makers in the region, towards a better tourism tax system for the sustainability of the ACS. Study outcomes provide insight into how the locals or indigenous people living nearby can take advantage of the benefits/opportunities derived from the site.
\end{abstract}

Keywords: eco-tourism; values of eco-tourism; values of cave system; linear probability; econometrics; cost-benefit analysis; tourism planning. 